Rodika Ursulesku-Miličić

UDC 811.135.1'367:811.163.41'367

Filozofski fakultet Univerziteta u Novom Sadu

Originalan naučni rad

rodika1969@gmail.com

\title{
RUMUNSKI EKVIVALENTI SRPSKOG PROSTORNOG GENITIVA ${ }^{1}$
}

Predmet ovog rada je kontrastivni opis genitivnih predloško-padežnih konstrukcija sa prostornim značenjem u srpskom i rumunskom jeziku. U radu se kontrastiraju dva semantička sistema čiji su članovi morfološki predstavljeni predloško-padežnim konstrukcijama koje su primarni sintaksički formalizator spacijalnosti i u rumunskom i u srpskom jeziku. Istraživanje spacijalnosti može biti bar dvostruko korisno: na ovaj način će se dobiti objašnjenje problema supstandardne upotrebe genitivnih padežnih konstrukcija u srpskom jeziku rumunskih govornika i srpskoj filološkoj javnosti će se predstaviti funkcionisanje rumunskog padežnog sistema u sferi spacijalnosti, što može biti od posebnog značaja za dalja dijalektološka istraživanja srpskih govora koji su zahvaćeni balkanizacijom. U radu su predstavljena spacijalna semantička potpolja u kojima su pronađeni primeri sa genitivom u srpskom jeziku i ekvivalenti u rumunskom jeziku.

Ključne reči: rumunski jezik, srpski jezik, padeži, genitiv, spacijalnost, semantika, sintaksa

\section{UVODNE NAPOMENE}

Kategoriju rumunskog padeža karakteriše visoki stepen obličke sinkretizovanosti. Sinkretizam imeničkih padeža razrešava se supstitutivnim poređenjem s odgovarajućim oblikom lične zamenice, čiji su padežni oblici nesinkretizovani. Naime, zamenom konkretnog imeničkog oblika odgovarajućim padežnim oblikom lične zamenice može se utvrditi padežni oblik imenice, up. subjekatsko Copilul merge 'Dete ide' $\mathrm{P}$ El merge 'On ide' sa objekatskim Mângâie copilul 'Miluje dete' P Îl mângâie ‘Miluje ga' (Gramatica Academiei I 2005: 70).

Sinkretizam oblika često predstavlja problem u rumunskom padežnom

1 Ovaj rad je realizovan u okviru projekta Jezici i kulture u vremenu i prostoru, br. Projekta 178002, finansiran od strane Ministarstva prosvete i nauke Republike Srbije. 
sistemu. A. Vatamaniuc (2008: 4) konstatuje da ako bismo posmatrali padeže samo iz morfološke perspektive broj padeža u rumunskom jeziku bio bi sveden na tri: a) nominativ - akuzativ, b) genitiv - dativ, c) vokativ, i to stoga što „nominativ ima uvek isti oblik kao i akuzativ, a ponekad i kao vokativ; genitiv ima uvek isti oblik kao i dativ, a ponekada, ako su imenice u množini sa određenim članom i sa vokativom“. Zbog toga, rumunski padežni sistem uvek moramo posmatrati iz semantičko-sintaksičke perspektive.

Genitiv može imati sintaksičku funkciju: 1) imenskog dela predikata, 2) genitivnog atributa, 3) atributa sa predlogom, 4) apozicije 5) indirektnog (nepravog) objekta, 6) priloške odredbe za mesto, 7) priloške odredbe za vreme, 8) priloške odredbe za način, 9) priloške odredbe za uzrok, 10) priloške odredbe za cilj (Negru 2003).

Uz rumunski genitiv stoje predlozi asupra, deasupra, contra, impotriva, inaintea, înapoia, imprejurul, ali i više predloških izraza, kao što su: în faţa, în mijlocul, în dreptul, de-a lungul, din cauza, în vederea (Iliescu 2005: 160).

U srpskom jeziku genitiv je tipično relacioni padež kojim se primarno definišu najrazličitiji sintaksičkosemantički odnosi među entitetima. On je u tom smislu funkcionalno najsloženiji, ali i najkompleksniji padež. Kako ističe K. Feleško (1995: 16), ,on može biti oblik kako adnominalne tako i adverbijalne odredbe: u pogodnim kontekstualnim uslovima može vršiti funkciju svakog člana rečenične konstrukcije; najzad, u raznim kontekstualnim varijantama može iskazivati neobično široku lepezu značenja između kojih je često teško uspostaviti izrazitu granicu. Sve ovo čini da se genitiv izdvaja od drugih padeža koji imaju preciznije funkcije. U slovenskim jezicima situaciju dodatno komplikuje sinkretizam starog ablativa i genitiva, a ako se uzme u obzir i primena genitiva sa predlogom, ta slika postaje još šarolikija.“ Osim toga srpskim genitivom mogu se identifikovati centralne sintaksičke funkcije (subjekatska i objekatska), i u tom smislu, poput nominativa i akuzativa, pripada centralnim padežima, koji se izdvaja obeležjem obuhvatnosti (Ivić M. 1983: 197).

U sferi prostorne adverbijalne determinacije srpski genitiv je direktivno nemarkiran padež, budući da je kombinabilan i sa direktivnim i sa indirektivnim glagolima, te se u tom smislu može praktično javiti i u sferi lokativnosti, i u sferi ablativnosti, i u sferi perlativnosti, i u sferi adlativnosti. Formalno gledano, spacijalni 
genitiv u srpskom jeziku uvek je blokiran predlogom. ${ }^{2}$

\section{SEMANTIČKO-SINTAKSIČKA ANALIZA SRPSKOG PROSTORNOG GENITIVA I NJEGOVI RUMUNSKI EKVIVALENTI}

U nastavku rada ćemo prikazati ona semantička potpolja u kojima se pojavljuju konstrukcije sa genitivom u srpskom jeziku i dajemo njihove ekvivalente na rumunskom jeziku. Ablativna intralokalizacija se formalizuje sledećim konstrukcijama sa genitivom: $\boldsymbol{i z}+\boldsymbol{g e n}-\boldsymbol{d e} \mathbf{l a}+\boldsymbol{a c c}:$ Od druma što dolazi $\boldsymbol{i z}$ Kirlibabe... (L.R., 9)/ Din şoseaua ce vine de la Cârlibaba...(L.R., 9) ${ }^{3} ; \boldsymbol{i z}+$ gen - de pe la + acc: Bila je seljačka kći, negde iz Monora ... (L.R., 23)/Era fată de ţăran de pe la Monor.... (L.R., 22); iz + gen - din + acc: ... nije čitavog dana izlazio iz kancelarije,... (L.R., 216)/ ...nu iessi toată ziua din cancelarie, ...(L.R., 207); iz + gen - de prin + acc: Gledale sa sokaka i iz susednih avlija ... (L.R., 29)/ Priveau din uliţă şi de prin ogrăzile vecine.... (L.R., 29); iz + gen - dintre + acc: Izbio je iz žbunja... (M.C.,20)/ $\underline{A}$ tâșnit dintre tufe...(M.C.,10).

Padežna konstrukcija $i z+$ gen u srpskom jeziku je stabilan formalizator ablativne intralokalizacije budući da se njome ne može predstaviti neki drugi tip spacijalne determinacije. $\mathrm{S}$ druge strane, kao što se vidi iz ekscerpiranih primera, $\mathrm{u}$ rumunskom jeziku se ablativna intralokalizacija formalizuje isključivo akuzativom, što je nedvosmislen pokazatelj relativizacije padežnog oblika u sferi spacijalne determinacije i prebacivanja sintaksičkog fokusa na inherentnu leksičku semantiku glagola u poziciji upravnog predikata, te na predlog.

U rumunskom jeziku u ovoj kategoriji akuzativni oblik imenice najčešće je

2 Broj predloga koji se pojavljuju uz genitiv je veći od broja predloga koji se vezuju za sve ostale padeže zajedno. K. Feleško uočava čak 52 predloga uz genitiv, a čak je 36 tipova ustanovljenih genitivnih predloških konstrukcija s ,primarnim prostornim značenjem“ (Feleško 1995: 78-79).

3 Primeri su ekscerpirani iz sledećih književnih dela: L.R. - Rebreanu, Liviu (1955), Ion, Bucureşti: Editura de stat pentru literatură şi artă. Rebreanu, Liviju (1957), Jon, Bukurešt: Državno izdavačko preduzeće za književnost i umetnost. Prevela Anđelka Tomić; M.C. Crnjanski, Miloš (1987), Seobe, Beograd: Nolit. Crnjanski, Miloš (1993), Migratiile, Timişoara: Editura de Vest. Preveli Dušan Bajski i Octavia Nedelcu; K.N. - Negrutzi Costache (1993), Alexandru Lăpuşneanul, Bucureşti: Editura Minerva. Negruci Kostake (1940), Aleksandar Lepušneanul, 1-25, u knjizi: Leposava Pavlović, Odlomci rumunske proze, Beograd: Srpska književna zadruga, knjiga 300, kolo XLIII. Prevela Leposava Pavlović.J.L.K. - Caragiale, Ion, Luca, (1994), Două loturi în Momente, Bucureşti: Editura Fundaţiei Culturale Române. Karađale, Jon, Luka (1940), Dva zgoditka, u knjizi: Leposava Pavlović, Odlomci rumunske proze, Beograd: Srpska književna zadruga, knjiga 300, kolo XLIII. Prevela Leposava Pavlović. 
blokiran predlogom din kao primarnim indikatorom početne tačke kretanja. Predlozi de la, dintre i de prin komutabilni su s opšteablativnim din. Sastavne komponente navedenih složenih predloga su sledeći prosti predlozi: de la - de +la; dintre - de + intre; de prin-de + prin (Cruceru 2005: 172).

Determinisana radnja uvek je leksikalizovana glagolima sa inherentnim leksičkim obeležjem [+ DIREKT].

Ablativna arealokalizacija formalizuje se u srpskom jeziku konstrukcijom $s(a)+$ gen, dok se u rumunskom jeziku pojavljuju sledeće padežne konstrukcije: din + acc i de pe + acc. Npr. s(a) + gen - din + acc: Jadna debeljuškasta sluškinja siđe pažljivo s kočija sa Laurinom ćerkicom u naručju... (L.R., 439)/ O servitoare dolofană coborî tacticos din trăsură cu fetiţa Laurei în braţe... (L.R., 413); Sǐšaoje

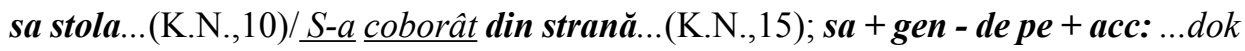
mu je znoj sa slepoočnica kapao na košulju. (L.R., 330)/ ... sudorile 1̣i curgeau de pe tâmple pe umerii cămăşii. (L.R., 312).

Predloško-padežne konstrukcije koje se pojavljuju u rumunskim primerima su prevodno ekvivalentne sa srpskom konstrukcijom $s(a)+$ gen.

Perlativna arealokalizacija se formalizuje na sledeći način: preko + gen peste + acc: Prelazi reku preko starog mosta... (L.R., 9)/_trece râul peste podul bătrân... (L.R., 9); On potrči...preko brda i reka...(M.C.,99)/ El trebuia să alerge, peste valuri, peste văi...(M.C.,81); preko + gen - pe + acc: Prevlačio gudalom preko strune... (L.R., 21)/ Târâia ....pe strune... (L.R., 21).

U sferi perlativne arealokalizacije i u srpskom i u rumunskom jeziku može se javiti više padežnih konstrukcija, pri čemu srpskom perlativnom akuzativu može konkurisati perlativno markirani slobodni instrumental, te direktivno nemarkirani genitiv, dok je u rumunskom jeziku u ovom semantičkom potpolju registrovan samo akuzativ.

Rumunski prevodni ekvivalent srpskom arealokacionom perlativnom predlogu preko je predlog peste. Većina registrovanih primera s ova dva predloga su kongruentni. ${ }^{4}$

Konstrukcije nasred + gen - în mijlocul + gen: Nasred puta drema pas... (L.R., 10)/ În mijlocul drumului picotește câinele... (L.R., 10); navrh + gen - în

$4 \quad$ Kongruentne konstrukcije su ekvivalentne konstrukcije koje su i formalno slične, odnosno konstrukcije koje se u dva jezika sastoje od elemenata koji pripadaju istoj vrsti reči i imaju istu sintaksičku funkciju (Đorđević 1982: 63). 
vârful + gen: ...uzalud kukuriče petao navrh crkve... (L.R., 222)/ ...degeaba cântă cocoşul în vârful bisericii... (L.R., 212) pripadaju lokativnoj centriranoj lokalizaciji.

Adlativna centrirana lokalizacija se u srpskom jeziku formalizuje konstrukcijama nasred + gen i usred + gen, a u rumunskom jeziku padežnom konstrukcijom în mijlocul + gen. Npr. Zastade nasred dvorišta.... (L.R., 28)/ Se opri în mijlocul ogrăzii... (L.R., 27); ... Banjska ulica skreće sa druma pravo usred Senđorza... (L.R., 440)/ Uliţa Băilor cotește din şoseaua cea mare în mijlocul Sângeorzului... (L.R., 414).

Primećuje se da se kao formalizatori adlativne centriranosti javljaju iste padežne konstrukcije sa istim međusobnim odnosima kao i u vezi sa lokativnošću (Pavlović 2000: 31). Adlativnost je u tom smislu kontekstualno identifikovana, tj. inherentnom leksičkom semantikom glagola.

Lokativna supralokalizacija se formalizuje sledećim konstrukcijama: iznad + gen - deasupra + gen: Ima kosmati mladež iznad leve obrve... (J.L.K.,56)/ Care are o aluniţă cu păr deasupra sprâncenii...(J.L.K.,66); iznad + gen - la + acc: Upalili im po voštanu sveću iznad glave...(J.L.K.,94)/ Le-au aprins câte o luminare de ceară la cap; (J.L.K.,99).

Ekvivalentne konstrukcije u rumunskom i srpskom jeziku su deasupra + gen i iznad + gen, i one se najčešće i pojavljuju u ovom semantičkom potpolju. Konstrukcije la $+a c c$ i spre $+a c c$ u ovom semantičkom potpolju su veoma retke.

Adlativna supralokalizacija se formalizuje sledećim konstrukcijama: iznad

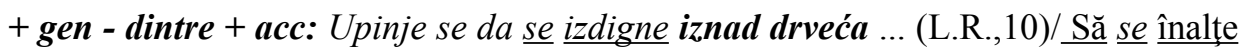
dintre crengile pomilor... (L.R., 10); iznad + gen - deasupra + gen: Pritom podiže pogled iznad škole, ka plavom nebu... (L.R., 222)/Ridică ochii mai sus deasupra şcolii, spre cerul albastru... (L.R., 212).

Konstrukcije iznad + gen i deasupra + gen su primarni indikatori supralokalizacije, ali budući da se radi o direktivno nemarkiranim modelima, adlativnost biva kontekstualno identifikovana, prvenstveno direktivnošću glagola u poziciji upravnog predikata.

Adlativna sublokalizacija se formalizuje sledećim konstrukcijama sa genitivom: ispod + gen - sub + acc: I otišlo da mirno legne ispod kreveta. (J.L.K.,87)/

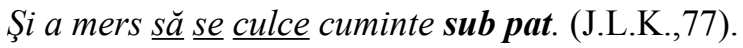

Srpski genitiv s predlogom ispod je direktivno nemarkirana konstrukcija 
koja se može javiti i u sferi lokativnosti i u sferi adlativnosti.

Lokativna antelokalizacija je tip "donje" prostorne lokalizacije specifikovan odsustvom usmerenog (direktivnog) kretanja. Primeri sa prostornim genitivom su sledeći: ispred + gen - în dreptul + gen: Na pervazu predvorja, ispred vrata, gde se izjutra umiva učitelj... (L.R., 10)/ Pe prichiciul pridvorului, în dreptul uşii, unde se spală învăţătorul.... (L.R., 10); ispred + gen - înaintea + gen: Na nekoliko koraka ispred konja vidim neko malo stvorenje koje poskakuje...(J.L.K.,84)/ La câţ̧iva paşi înaintea calului zăresc o mogândeaţă mică sărind şi ţopăind. (J.L.K.,74).

Kao što se može videti iz navedenih primera, u rumunskom jeziku u ovom tipu spacijalne determinacije dominiraju predloškopadežne konstrukcije s predloškim izrazima în dreptul (drept(ul) 'pravo'), în fruntea (frunte(a) ‘čelo'), în faţa, din faţa, (faţă 'lice'). Imenice koje ulaze u sastav rumunskog predloškog izraza uvek su sa određenim članom $(\boldsymbol{u}) \boldsymbol{l}$ (za imenice muškog roda), odnosno $\boldsymbol{a}$ (za imenice ženskog roda). Za sve ove predloške izraze možemo reći da su sinonimični, i svi oni se mogu prevesti srpskim predlozima „ispred“ ili „pred“. U ovom semantičkom potpolju se pojavljuje i predlog înaintea, ${ }^{5}$ koji se uvek kombinuje sa genitivom, i iskazuje prostorni odnos pokazujući mesto ispred nekoga ili nečega. Stoga za njega možemo konstatovati da je sinonimičan sa navedenim predloškim izrazima, a na srpski jezik se takođe uvek prevodi predlozima ispred ili pred (Živković 1999).

Ablativna antelokalizacija tip "prednje" prostorne lokalizacije specifikovan fokusiranjem početne tačke usmerenog (direktivnog) kretanja. Ovaj tip prostorne determinacije u rumunskom jeziku formalizuje se padežnom konstrukcijom înaintea + gen, dok se u srpskom ona realizuje konstrukcijom ispred + gen: Npr. Bacila se

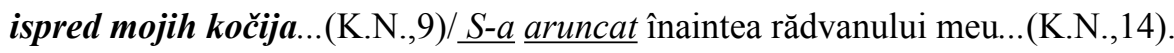

$\mathrm{S}$ obzirom na to da se predlog înaintea na rumunskom jeziku uvek prevodi na srpski predlogom ispred i da su na oba jezika prisutne konstrukcije sa genitivom, možemo govoriti o potpunoj ekvivalenciji. I rečenice koje su date kao ilustracija ablativne antelokalizacije su ekvivalentne i kongruentne.

Lokativna postlokalizacija je tip "zadnje" prostorne lokalizacije specifikovan odsustvom usmerenog (direktivnog) kretanja. Primeri sa genitivom su sledeći: $\boldsymbol{i z a}+$ gen - în dosul + gen: Iza šupe beše oveći voćnjak... (L.R., 19)/ În dosul şurii era o livadă mărişoară... (L.R., 19); iza + gen - în + acc: Nesreća kao da je bila ostala, iza

5 Up. "prepoziţia înaintea este construită cu genitiv... exprimă un raport spaţial, indicând locul din faţa cuiva sau a ceva - Se află înaintea mea" (Nalazi se ispred mene) (DEX 1998) 
njega...(M.C.,25)/ Ca şi când necazurile ar fi rămas în urmă...(M.C.,14); iza + gen - după + acc: Koja se srnela iza drveća... (M.C.,190)/ Ce se deslusea după arbori... (M.C.,161); iza + gen - la spatele + gen: Iza svakog bojara stajao je po jedan poslužitelj...(K.N.,12)/ La spatele fieştecăruia boier dvorea câte o slugă...(K.N.17).

Kao prevodni ekvivalenti srpskog predloga $i z a$, u rumunskom jeziku se pojavljuje predlog după koji se uvek kombinuje sa akuzativom i koji pokazuje posteriornost u prostoru (DEX 1998), ali i predloški izrazi în dosul i la spatele, koji su zapravo kombinacije predloga i odgovarajuće imenice: dos 'zadnja strana, leđa', spate(le) 'leđa'.

Ablativna postlokalizacija se u rumunskom jeziku formalizuje padežnim konstrukcijama de după + acc i în spatele + gen, dok se u srpskom jeziku imamo konstrukciju iza + gen. Npr. iza + gen - de după + acc: Pojavio se iza šupe ... (L.R., 28)/ Sosind tot de după şură... (L.R., 28); iza + gen - în spatele + gen: Iza kojih se sad pomaljalo Sunce...(M.C.,26)/ În spatele cărora se profila soarele...(M.C.,15).

S obzirom na to da se navedena padežna konstrukcija uz glagole sa obeležjem [- DIREKT] u srpskom jeziku pojavljuje i kao formalizator perlativnosti i adlativnosti, ablativnost mora biti podržana ablativno markiranim glagolom, odnosno kontekstom.

Perlativna postlokalizacija se u rumunskom jeziku formalizuje padežnom konstrukcijom pe + acc, a u srpskom jeziku konstrukcijom iza + gen: U sobi gospa Margioale gori svetlo, a senke se kré́u iza zavese...(J.L.K.,87)/La odaia cocoanii Marghioalii lumină, şi umbre mișcă pe perdea...(J.L.K.,77).

Adlativna postlokalizacija je tip "zadnje" prostorne lokalizacije specifikovan fokusiranjem završne tačke usmerenog (direktivnog) kretanja i kada govorimo o konstrukcijama sa genitivom dajemo sledeće primere: $\boldsymbol{i z a}+$ gen - printre + acc: Malo će se sakriti iza mladih bukava... (L.R., 9)/ Ascunzându-se printre fagii tineri... (L.R., 9); iza + gen - în spatele + gen: I završavala iza Avrumove kafane... (L.R., 19)/ Se oprea chiar în spatele cârciumii... (L.R., 19).

Ako govorimo o potpunoj ekvivalenciji konstrukcija na rumunskom $\mathrm{i}$ srpskom jeziku, onda su to samo konstrukcije în spatele + gen i iza + gen. U okviru ove kategorije pojavljuje se i konstrukcija printre $+a c c$, koja nije karakteristična za ovo semantičko potpolje. ${ }^{6}$

6 U primeru Ascunzându-se printre fagii tineri...- Malo će se sakriti iza mladih bukava, srpskoj postlokacionoj konstrukciji iza + gen konfrontirana je rumunska primarno interlokaciona konstrukcija printre + acc. 
Lokativna interlokalizacija se formalizuje sledećim konstrukcijama sa genitivom: između +gen - între + acc: $U$ dvorištu, između dve mlade jabuke, večito je razapeto uže... (L.R., 10)/ În ogradă, între doi meri tineri, e întinsă frânghia... (L.R., 10); između + gen - printre + acc: ... i kriju se izmedu starih borova... (L.R., 440)/ ... ascunse printre brazi bătrâni,.... (L.R., 415).

Konstrukcije între + acc i između + gen su u potpunosti prevodno ekvivalentne i primeri koji ih ilustruju su kongruentni. Ostale konstrukcije su samo prevodni ekvivalenti. Predlozi între i printre su sinonimi ${ }^{7}$ i iskazuju mesto između više osoba ili stvari (DEX 1998).

Perlativna interlokalizacija je tip prostorne međulokalizacije specifikovan fokusiranjem pravca usmerenog (direktivnog) kretanja. Ovaj tip prostorne determinacije u rumunskom jeziku formalizuje se padežnom konstrukcijom printre $+a c c$, a u srpskom jeziku se pojavljuje konstrukcija između + gen. Ove padežne konstrukcije su u potpunosti prevodno ekvivalentne: izmedu + gen - printre + acc: Kad projahaše između dva brežuljka...(M.C.,135)/_Trecură călare printre două povârnişuri...(M.C.,113).

Determinisani predikat predstavljen je glagolskim izrazom sa inherentnim semantičkim obeležjem [+ DIREKT]: a trece călare 'projahati' ${ }^{8} \mathrm{~S}$ obzirom na to da je srpska konstrukcija između + gen direktivno nemarkirana konstrukcija, primarni indikator perlativnosti je kontekst, odnosno inherentna leksička semantika glagola srpski glagol prefigiran je prefiksom pro- kao opštim markerom perlativnosti.

Lokativna jukstalokalizacija se $\mathrm{u}$ oba jezika formalizuje velikim primerom konstrukcija sa genitivom: kod + gen - la + acc: Kod Avrumove kafane oseća se... (L.R., 11)/ De-abia la cârciuma lui Avrum se simte... (L.R., 11); kraj + gen - la + acc: Tit odjednom zastade kraj prozora... (L.R., 221)/ Deodată Titu se opri la o fereastră... (L.R., 211); kraj + gen - lângă + acc: Ostade sa svojima kraj šupe... (L.R., 31)/ Rămase cu ai lui lângă şură... (L.R., 30); oko + gen - în jurul + gen: Svi se parovi tiskaju oko sviraca... (L.R., 13)/ Se îmbulzesc în jurul lăutarilor... (L.R.,

7 Up. "prepoziţia printre ...exprimă spaţiul între mai multe fiinţe sau obiecte - Trăieşte printre străini" (Živi među strancima) (DEX 1998).

8 U ovom primeru imamo na rumunskom jeziku glagolski izraz a trece călare ('proći na konju'), umesto glagola a călări ('jahati'). Prevodilac je upotrebio glagolski izraz zbog toga što u srpskom primeru imamo prefiksirani glagol (,projahati”), a u rumunskom ne postoji odgovarajući glagol sa prefiksom. Da nije upotrebljen glagolski izraz, ovaj primer ne bi spadao u kategoriju perlativne interlokalizacije, već bi pripadao lokativnoj interlokalizaciji. 
12); oko + gen - pe la + acc: Muškarci se drže više po strani, kraj kuće, oko kapije ... (L.R., 14)/ Bărbaţii se tin mai departe, pe lângă casă, pe la poartă ... (L.R., 9); blizu + gen - în preajma + gen: Sveštenikova kuća nalazila se blizu crkvice...(L.R., 224)/ Casa preotească era în preajma bisericuţei... (L.R., 215); oko + gen - pe + acc: A oko vrata joj je visila ogrlica...(K.N.,7)/ Pe grumazii ei atârna o salbă...(K.N.,12); blizu + gen - în apropierea + gen: Kola se najzad zaustaviše blizu jednog kućerka... (J.L.K.,54)/ Se oprește în sfârşit în apropierea unei cocioabe...(J.L.K.,64); oko + gen - printre + acc: Prokleti mačor! sve se nešto mota ljudima oko nogu. (J.L.K.,83)/ Afurisit cotoi! se tot vârá printre picioarele oamenilor. (J.L.K.,73).

Rumunska konstrukcija lângă + acc je prevodni ekvivalent srpskoj konstrukciji kraj + gen. Pored konstrukcije lângă + acc u rumunskom jeziku se javlja i konstrukcija sa složenim predlogom pe lângă, i one su sinonimične (Bulgăr 1996).

U konstrukcijama în preajma + gen i în apropierea + gen javljaju se predloški izrazi sastavljeni od predloga în i odgovarajuće imenice: preajmă 'komšiluk, blizina', apropiere 'blizina'. Imenice koje se nalaze u sastavu ovih konstrukcija uvek imaju određeni član i sinonimične su (Iliescu 2005: 256). Ovi predloški izrazi su prevodni ekvivalenti srpske konstrukcije blizu + gen.

Konstrukcija în jurul + gen na rumunskom jeziku je prevodni ekvivalent srpske konstrukcije oko + gen (Živković 1999).

$\mathrm{U}$ okviru ove kategorije se pojavljuje i primer sa konstrukcijom pe $+a c c-$ (Pe grumazul ei atârna o salbă...(K.N.,12)), koja se nalazi u kombinaciji sa srpskom konstrukcijom oko + gen - (A oko vrata joj je visila ogrlica...(K.N.,7)). Ovde je upotrebljen predlog $p e$, a ne predloški izraz în jurul, koji bi bio prevodni ekvivalent srpskom predlogu oko, zbog toga što se uz imenicu grumaz 'vrat', u ovom kontekstu mora upotrebiti predlog pe.

Zanimljiv je i primer sa konstrukcijom printre $+a c c$, koja je prevedena srpskom konstrukcijom oko + gen: (Afurisit cotoi! se tot vârá printre picioarele oamenilor. (J.L.K.,73) - Prokleti mačor! sve se nešto mota ljudima oko nogu. (J.L.K.,83)). Izbor konstrukcija ovde je diktiran različitim izborom glagola u poziciji upravne predikacije. Rumunski glagol a se vârî zapravo znači „,ugurati se” (Živković 1999). Ako se pođe od semantike rumunskog glagola, izbor predloga printre kao primarnog indikatora interlokalizacije sasvim je logičan.

Ablativna jukstalokalizacija se formalizuje sledećim konstrukcijama: od + 
gen - din + acc: Od druma što dolazi iz Kirlibabe ... sve do Kluža ... (L.R., 9)/Din şoseaua ce vine de la Cârlibaba.....până la Cluj ...(L.R., 9); od +gen - de + acc: ...kad je pristao da pođe od kuće... (L.R., 215)/ ...s-a învoit să plece de-acasă... (L.R., 205); od + gen - de la + acc: Skočio je od stola skoro očajno... (L.R., 220)/ Sări de la masă aproape desperat... (L.R., 211);

Rumunske konstrukcije de la $+a c c$ i $d e+a c c$ su prevodni ekvivalenti srpskog genitiva s predlogom $o d$. Konstrukcija $d i n+a c c$, mada primarno indikator ablativne intralokalizacije, ulazi u sferu ablativne jukstalokalizacije upravo na bazi svoje ablativnosti, pri čemu pozicioni parametar očigledno može biti i zanemaren (up. Živković 1999). Činjenica je da distribucija predloga u pojedinim kategorijama zavisi od osećaja prevodioca.

Budući da se konstrukcija od + gen u srpskom jeziku ne javlja kao formalizator drugih tipova jukstalokalizacije, predlog $o d$ je dovoljan indikator ablativnosti.

Konstrukcije kraj + gen - pe lângă + acc: Prođoše kraj ogromnih peći... (M.C.,95)/ Soldaţii trecură pe lângă cuptoare...(M.C.,78); pokraj + gen - pe lânğ + acc: Prošao pokraj njihovog stola...(J.L.K.,58)/_Trece pe lângă masa lor către fund...(J.L.K.,68) su karakteristične za perlativnu jukstalokalizaciju. Adlativna jukstalokalizacija se formalizuje na sledeći način: $\boldsymbol{d o}+\boldsymbol{g e n}$ - până la acc: $\underline{\text { Pokloniše }}$ se do zemlje...(K.N.,2)/ Se închinară până la pământ...(K.N.,7); do + gen - la + acc: Pri zalasku sunca, stiže putnik do krajovske straže...(J.L.K.,112)/ Pe la asfinţit a ajuns drumeţul la straja Craiovei...(J.L.K.,117); do + gen - până-n + acc: Prašina se diže sve do gredica... (L.R., 13)/ Se urcă până-n căpriori... (L.R., 13); do + gen - în mijlocul + gen: Se dovlači do devojaka... (L.R.,16)/ Se târâie în mijlocul fetelor... (L.R., 16); do + gen - în vârful + gen: Uspe se do prozorčeta...(J.L.K.,61)/ Se apropie în vârful galoşilor de ferestruică...(J.L.K.,71).

Konstrukcije până la $+a c c$, până în + acc i la $+a c c$ su prevodno ekvivalentne srpskoj konstrukciji do + gen. Rumunske konstrukcije su sinonimične (Bulgăr 1996). Primeri sa konstrukcijom până la + acc su kongruentni. U okviru ove kategorije pojavljuju se i konstrukcije sa predloškim izrazima în vârful + gen i în mijlocul + gen .

\section{ZAKLJUČAK}

U ovom radu prikazan je kontrastivni opis sistema genitivnih predloško- 
padežnih konstrukcija sa prostornim značenjem u rumunskom i srpskom jeziku. U radu se kontrastiraju semantička potpolja u kojima se pojavljuju konstrukcije sa genitivom, i to: ablativna intralokalizacija, ablativna arealokalizacija, perlativna arealokalizacija, adlativna centrirana lokalizacija, adlativna supralokalizacija, adlativna sublokalizacija, lokativna antelokalizacija, ablativna antelokalizacija, lokativna postlokalizacija, abaltivna postlokalizacija, perlativna postlokalizacija, adlativna postlokalizacije, lokativna interlokalizacije, perlativna interlokalizacija, lokativna jukstalokalizacija, ablativna jukstalokalizacija.

Kao što se moglo videti iz analize ekscerpiranih primera, broj predloga $\mathrm{i}$ predloških izraza u rumunskom jeziku mnogo je veći nego u srpskom jeziku, gde se mnoga semantička potpolja formalizuju samo jednom predloško-padežnom konstrukcijom. Rumunski genitiv javlja se sporadično po pravilu u kombinaciji sa predloškim izrazima, uz koje je upotreba genitivnog oblika imenice motivisana posesivnom relacijom između partikularizatora i celine, odnosno posesuma i posesora.

Što se tiče glagola, srpski jezik favorizuje upotrebu prefiksa kojima se vrlo često specifikuje tip dinamičnosti, odnosno direktivnost. Najčešći srpski prefiksi su od-, do- i pre- . Rumunski jezik ne ispoljava potrebu za ovim tipom isticanja direktivnosti.

Na kraju, možemo konstatovati da i rumunski i srpski jezički sistem raspoloživim padežnim formama, u ovom slučaju genitivom, uspeva formalizovati različite vrste spacijalnosti, s tim što je u rumunskom jeziku „manjak“ padežnih formi nadoknađen višim komunikativnim značajem predloga i inherentne semantike upravnog glagola.

\section{LITERATURA}

Academia Română (Institutul de lingvistică „Iorgu Iordan - Al. Rosetti”) (2005). Gramatica limbii române I. Cuvântul. Bucureşti: Editura Academiei Române. Bulgăr, Gheorghe (1996). Dicţionar de sinonime. Bucureşti: Editura Palmyra.

Cruceru Constantin şi Vasile Teodorescu (2005). Gramatica limbii române. Bucureşti: Editura 100+1 GRAMAR.

DEX: Dicţionarul Explicativ al Limbii Române (1998). Bucureşti: Editura Univers Enciclopedic. 
Đorđević, Radmila (1982). Uvod u kontrastiranjejezika. Beograd: Univerzitet u Beogradu, Filološki fakultet.

Feleško, Kazimjež (1995). Značenja i sintaksa srpskohrvatskog genitiva. Novi Sad-Beograd: Matica srpska-Vukova zadužbina-Orfelin.

Iliescu, Ada (2005). Gramatica practică a limbii române. Bucureşti: Editura Corint.

Ivić, Milka (1983). Lingvistički ogledi. Beograd: Prosveta.

Jivcovici, Mirko (1999). Dicţionar sârb-român şi român-sârb. Bucureşti: Editura Teora.

Negru Mariana şi Mariana Badea(2003). Limba română. Gramatica pentru elevi. Bucureşti: Editura Badea.

Pavlović, Slobodan (2000). Determinativni padeži u govoru severozapadne Boke. Beograd: Institut za srpski jezik, SANU.

Piper, Predrag (2001). Jezik i prostor. Beograd: BIBLIOTEKA XX VEK.

Vatamaniuc, A. (2007). Funcţiile şi semnificaţiile cazurilor în limba română, teză de doctorat, susţinută pe 8 noiembrie 2007, la Institutul de Filologie al Academiei de Ştiinţe a Moldovei, Chişinău.

Ursulesku-Miličić, Rodika (2009). Spacijalne padežne konstrukcije u rumunskom i srpskom jeziku. Magistarski rad, Novi Sad: Filozofski fakultet.

Rodika Ursulesku-Miličić

\section{ROMANIAN EQUIVALENTS OF THE SERBIAN SPATIAL GENITIVE}

\section{Summary}

This paper is about a contrastive analyses study of the prepositional-casual spatial constructions with genitive in the Romanian and Serbian Language. It is the intention of the author to contrast two semantic systems consisting of parts which are morphologically represented by prepositional and case structures. Primary syntactic formalizers of spatiality in both the Romanian and Serbian language are either case structures, or combinations made of case structure followed by preposition. This research could be useful for at least two reasons: firstly - the problem of the substandard use of case structures with genitive used in the Serbian language spoken by Romanian speakers 
could be explained, and secondly - philological audience could obtain important data about spatial aspects of the Romanian case system, which is of great importance for further research of Serbian dialects influenced by Balkanisation process. The paper presents spatial semantic subfields consisting of examples with genitive in the Romanian and Serbian language. Examples illustrating Romanian equivalents of spatial genitive in Serbian language are extracted from Serbian literary work translated in Romanian language and vice versa.

Keywords: Romanian language, Serbian language, cases, genitive, spatiality, semantics, syntaxis 